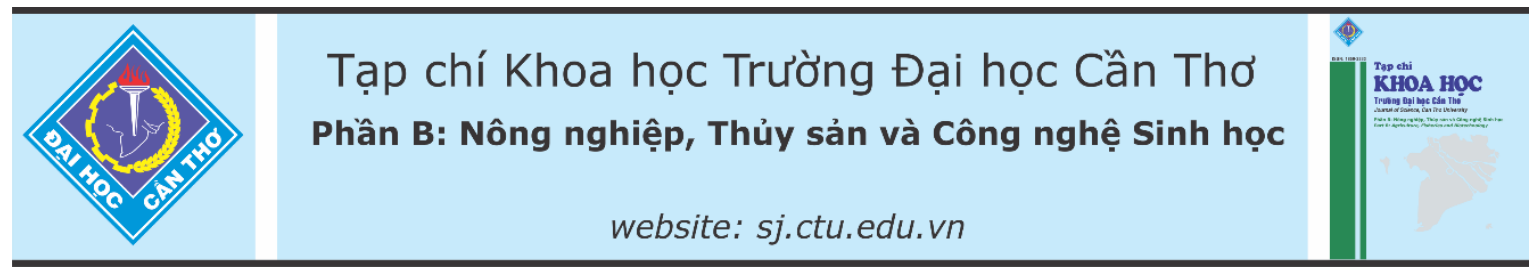

DOI:10.22144/ctu.jvn.2021.049

\title{
HIỆN TRẠNG NUÔI TÔM THẺ CHÂN TRÁNGG (Litopenaeus vannamei) TẠI HỢP TÁC XÃ NUÔI TÔM NĂNG SUÂTT CAO TÂN HƯNG, HUYỆN CÁI NƯớC, TİNH CÀ MAU
}

\author{
Lê Thị Phương Mai ${ }^{1 *}$, Nguyễn Văn Nay ${ }^{1}$ và Lưu Tiến Thuận ${ }^{2}$ \\ ${ }^{1}$ Khoa Phát triển Nông thôn, Truoòng Đại học Cần Tho \\ ${ }^{2}$ Khoa Kinh tế, Truờng Đại học Cần Tho \\ *Nguời chịu trách nhiệm về bài viết: Lê ThịPhuoong Mai (email: ltpmai@ctu.edu.vn)
}

\section{Thông tin chung:}

Ngày nhận bài: 06/10/2020

Ngày nhận bài sưa: 09/12/2020

Ngày duyệt đăng: 28/04/2021

\section{Title:}

The status of cultural white leg shrimp (Liptopenaeus vannamei) in Tan Hung cooperative high yield shrimp production, Cai Nuoc district, Ca Mau province

\section{Tù khóa:}

Hợp tác xã, kỹ thuật, lọi ích, tài chinh

\section{Keywords:}

Cooperative, technique, benefit, finance

\section{ABSTRACT}

The study aimed to assess the status and benefits of farmers participated in Tan Hung agricultural cooperative high yield shrimp production regarding to technical and financial aspects by interviewing 30 cooperative members in Cai Nuoc district, Ca Mau province. Data collected involved technical situation and benefits of farmer being member of the cooperative. The result indicated the average yield and profit of the farm were 3.97 tons/1,000 $\mathrm{m}^{2} /$ crop and 137 million VND /1,000 $\mathrm{m}^{2} /$ crop respectively. Profit margin of shrimp farming was approximately 0.42 and economic lost household ratio was $23.3 \%$. The farmers participating in the cooperative achieved economic and association benefits significantly. With regard to economic aspect, being member of cooperative result in revenue and profit improving due to increasing productivity, reducing production costs, and stable selling price. The association aspect bring several benefit to members including inputs and services concession, accessing technical support, output's quality improvement, build up association, and information and experiments sharing. The difficulties of cooperative included capital shortage, product consumption, the limitation of cooperative leaders' management capacity, small scale production, and lack of belief between stakeholders.

\section{TÓM TẮT}

Nghiên cúu nhằm đánh giá hiện trạng và nhũng lợi ich khi tham gia hơp tác xã (HTX) thông qua việc phỏng vấn trục tiếp 30 thành viên nuôi tôm thuộc HTX Nuôi tôm Năng suất cao Tân Hưng, huyện Cái Nước, tỉnh Cà Mau. Các thông tin thu thập gồm hiện trạng kỹ thuật và nhũng lợi ich của người nuôi tôm khi tham gia HTX. Kết quả nghiên cưu cho thấy năng suất trung bình đạt 3,97 tấn $/ 1.000 \mathrm{~m}^{2} / v u$ và lợi nhuận trung bình là 137 triệu đồng $/ 1.000 \mathrm{~m}^{2} / v u$. Tỷ suất lợi nhuận là 0,42 và 23,3\% hộ nuôi thua lỗ. Khi tham gia HTX, thành viên có được lợi ich về kinh tế và hiệp hội. Lợi ich kinh tế bao gồm việc tăng doanh thu và lợi nhuận do tăng sản luợng, giảm chi phi đầu vào và giá bán ổn đinh. Lợi ich về khía cạnh hiẹp họi bao gồm các yếu tố: được ưu đãi giá vật tu và các dịch vu đầu vào, được hỗ trợ về kỹ thuật, chất luợng đầu ra sản phẩm tốt hơn, xây dựng mối liên kết và tạo môi truờng hợp tác, được trao đổi và chia sẻ kinh nghiệm trong sản xuất. Các khó khăn của HTX là thiếu vốn, tìm đầu ra cho sản phẩm, năng lực điều hành của lãnh đạo HTX còn hạn chế, thành viên HTX chuva tích cực và còn trông chờ nhiều vào sụ hố trợ, qui mô sản xuất còn nhỏ lẻ, chưa xây dựng được niềm tin giũa các bên liên kết. 


\section{GIỚI THIÊU}

Theo Hiệp hội chế biến và xuất khẩu Thủy sản Việt Nam (VASEP, 2019), sản lượng thủy sản Việt Nam đã duy trì tăng trưởng liên tục trong 17 năm qua với mức tăng bình quân là $9,07 \% /$ năm và sản lượng nuôi trồng tăng bình quân $12,77 \%$ /năm với diện tích nuôi tôm cả nước đạt 720.000 ha, sản lượng tôm sú ước đạt 270.000 tấn và tôm thẻ chân trắng là 480.000 tấn. Trong đó, diện tích nuôi thủy sản nước lợ, mặn ở Đồng bằng sông Cửu Long (ĐBSCL) chiếm khoảng $90 \%$ tổng diện tích tiềm năng nuôi trồng thủy sản cả nước (Nguyễn Thanh Phương và ctv., 2014). Tôm thẻ chân trắng (Penaeus vannamei) được nhập vào và nuôi thử nghiệm ở Việt Nam vào năm 2000 (Hoàng Tùng và ctv., 2016) ĐBSCL là vùng nuôi tôm thẻ chủ lực của cả nước, chiếm $94 \%$ tổng diện tích nuôi và $70 \%$ sản lượng tôm thẻ của cả nước và có xu hướng tăng nhanh trong thời gian tới (Hoàng Tùng và ctv., 2016; Trần Ngọc Hải và ctv., 2017). Tại tỉnh Cà Mau, diện tích nuôi tôm tăng theo thời gian với 295,8 nghìn ha năm 2013 tăng lên 301,5 ha vào năm 2016 và 302,4 nghìn ha năm 2018 (Tổng cục Thống kê, 2019). Tôm thẻ tại Cà Mau được nuôi với nhiều hình thức đa dạng như nuôi ở qui mô nông hộ, doanh nghiệp, trang trại hay hợp tác xã (HTX), tổ hợp tác. Theo Chambo (2009) và Adref (2011) HTX nông nghiệp có vai trò quan trọng trong phát triển nông thôn thông qua việc phát triển các hoạt động nông nghiệp, góp phần tạo ra việc làm, phát triển thị trường, cải thiện thu nhập và tiếp cận các dịch vụ xã hội. Ở ĐBSCL, việc thành lập và phát triển HTX nông nghiệp diễn ra mạnh mẽ trong những năm gần đây. Hiện nay, số lượng HTX tính đến tháng 3/2019 ở ĐBSCL là 2.560 HTX (Liên minh HTX Việt Nam, 2019) và tính đến ngày 30/4/2019 tại Cà Mau có 129 HTX trong đó có 79 HTX thủy sản (Liên minh HTX Cà Mau, 2019).

Nghiên cứu trường hợp HTX Nuôi tôm Năng suất cao Tân Hưng, huyện Cái Nước, tỉnh Cà Mau nhằm phân tích hiện trạng kỹ thuật, tài chính và hoạt động của HTX. Kết quả nghiên cứu ngoài đánh giá hiện trạng kỹ thuật và tài chính còn phân tích những lợi ích về kinh tế và xã hội thành viên tiếp cận được khi tham gia hợp tác xã, đồng thời tìm hiểu những khó khăn của mô hình kinh tế hợp tác đang được Chính phủ khuyến khích phát triển này. Kết quả nghiên cứu sẽ cung cấp thêm các minh chứng thực tiễn khẳng định vai trò quan trọng của mô hình HTX trong hỗ trợ nông hộ nhiều khía cạnh trong sản xuất, đời sống cũng như những khuyến nghị trong tổ chức, quản lý và triển khai mô hình HTX nhất là HTX trong lĩnh vực nuôi trồng thủy sản.

\section{PHƯƠNG PHÁP THU THẬP THÔNG TIN VÀ XỬ LÝ SỐ LIỆU}

Nghiên cứu được thực hiện từ tháng 8 đến tháng 12 năm 2019 tại HTX Nuôi tôm Năng suất cao Tân Hưng, xã Tân Hưng, huyện Cái Nước, tỉnh Cà Mau thông qua phỏng vấn trực tiếp tất cả các thành viên của HTX (30 thành viên) bằng phiếu phỏng vấn soạn sẵn. Các chỉ tiêu thu thập bao gồm các thông tin về kỹ thuật và tài chính của mô hình như diện tích nuôi, mực nước, mật độ thả, hệ số chuyển hóa thức ăn (FCR), năng suất, chăm sóc, quản lý, giá bán, tổng thu, tổng chi và những lợi ích khi tham gia HTX. Số liệu thứ cấp được thu thập từ các báo cáo khoa học đã công bố, các báo cáo của HTX và Liên minh HTX, các số liệu thống kê từ Tổng cục Thống kê.

Số liệu sau khi thu thập được kiểm tra, mã hóa và nhâp liệu bằng Excel. Sau đó số liệu được tính trung bình, độ lệch chuẩn và được trình bày bằng thống kê mô tả (trung bình \pm độ lệch chuẩn). Các ý kiến của nông hộ được mã hóa chuyển từ dạng định tính sang định lượng và tính phần trăm.

\section{KẾT QUẢ VÀ THẢO LUẬN}

\subsection{Thông tin chung về nông hộ}

Kết quả khảo sát (Bảng 1) cho thấy tuổi của thành viên nuôi tôm thẻ chân trắng trung bình là 41,6 và $86,7 \%$ nam giới chịu trách nhiệm chính với hoạt động nuôi tôm. Điều này phản ánh nuôi tôm là công việc đòi hỏi có đầy đủ sức khỏe để thực hiện các công việc ngoài trời, nặng nhọc, thường xuyên tiếp xúc với môi trường nước và thành viên $\mathrm{HTX}$ đáp ứng tốt với yêu cầu đó. Tương tự với kết quả nghiên cứu của Lê Xuân Sinh và ctv. (2006), tỷ lệ nam giới quyết định trong hoạt động nuôi trồng thủy sản chiếm $75,7 \%$ và có $100 \%$ nam giới phụ trách các hoạt động nuôi tôm thẻ chân trắng ở Cà Mau (Nguyễn Thanh Long \& Huỳnh Văn Hiền, 2015).

Với diện tích nhỏ do nuôi ao lót bạt và được đầu tư trang thiết bị hiện đại như hệ thống cấp thoát nước, chăm sóc, quản lý chủ động và thuận tiện nên số thành viên tham gia trực tiếp nuôi tôm trung bình 2,1 người/hộ, đủ nhu cầu lao động phục vụ cho các hoạt động và công việc trong quá trình nuôi tôm. Số năm kinh nghiệm của thành viên nuôi bằng hình thức ao lót bạt trung bình 2,4 năm so với tổng số năm kinh nghiệm nuôi tôm trung bình là 6,3 năm vì mô hình nuôi tôm thẻ chân trắng trên ao lót bạt mới phát triển ở huyện Cái Nước trong những năm gần đây. Những thành viên nuôi tôm lâu năm sẽ thuận lợi hơn trong việc phát hiện và xử lý rủi ro do tích lũy được nhiều kinh nghiệm trong quá trình nuôi. 
Bảng 1. Một số thông tin chung về thành viên của HTX

\begin{tabular}{lrrr}
\hline Chỉ tiêu & Cao nhất & Thấp nhất & Trung bình \\
\hline Tuối của xã viên nuôi tôm (tuồi) & 64 & 23 & $41,6 \pm 10,6$ \\
Số thành viên trong gia đình (người/hộ) & 7 & 2 & $4,6 \pm 1,1$ \\
Số lao động tham gia nuôi tôm (người/hộ) & 1 & 4 & $2,1 \pm 0,8$ \\
Số năm kinh nghiệm nuôi tôm (năm) & 1 & 18 & $6,3 \pm 4,4$ \\
Số năm kinh nghiệm nuôi tôm ao bạt (năm) & 1 & 6 & $2,4 \pm 1,2$ \\
\hline
\end{tabular}

(Nguồn: Kết quả khảo sát năm 2019, n=30)

Trình độ học vấn của các thành viên nuôi tôm trong HTX chủ yếu ở cấp 2 (43,3\%), kế đến là cấp $1(26,7 \%)$, cấp 3 là $23,3 \%$ và trên cấp 3 là $6,7 \%$, những thành viên có trình độ trên cấp 3 chủ yếu là các thành viên thuộc ban quản lý HTX. Khảo sát của Nguyễn Thanh Long (2016) cũng cho thấy các hộ nuôi tôm ở Cà Mau có trình độ học vấn chủ yếu ở cấp 2 với $40,0 \%$, cấp 1 chiếm $22,8 \%$ nhưng cấp 3 chiếm cao hơn với $34,3 \%$ và trên cấp 3 chỉ $2,9 \%$. Tuy không có thành viên nào mù chữ nhưng qua quan sát thực tế, nhiều thành viên hạn chế về khả năng đọc, viết chữ và những thành viên này đa số thuộc nhóm lớn tuổi. Thực trạng này ảnh hưởng đến khả năng tiếp thu và áp dụng các tiến bộ khoa học công nghệ, đặc biệt là các công nghệ cao vào sản xuất và sẽ ảnh hưởng đến năng suất và hiệu quả của mô hình nuôi. Do vậy HTX có cán bộ kỹ thuật phụ trách hỗ trợ và chuyển giao khoa học kỹ thuật trực tiếp cho các thành viên trong suốt quá trình nuôi.

\subsection{Các chỉ tiêu kỹ thuật chính của mô hình nuôi thâm canh tôm thẻ chân trắng tại HTX Tân Hưng}

Các yếu tố kỹ thuật của mô hình nuôi tôm thẻ chân trắng được thể hiện ở Bảng 2. Diện tích tổng trang trại dao động từ $0,4-15$ ha nhưng diện tích trung bình ao nuôi là khá nhỏ, chỉ từ $0,11 \pm 0,04$ ha với độ sâu trung bình là $1,5 \mathrm{~m}$. Trong nuôi tôm thâm canh, đặc biệt là nuôi ao lót bạt, ao thường được thiết kế với diện tích nhỏ nhằm thuận tiện cho việc đầu tư trang thiết bị tự động cũng như việc chăm sóc và quản lý và thu hoạch. Ao nuôi tôm thẻ thường được thiết kế có hình vuông, góc bo tròn với diện tích từ $0,1-0,2$ ha và độ sâu từ $1,2-1,5 \mathrm{~m}$ (Trần Ngọc Hải và ctv., 2017). Theo Nguyễn Thanh Long và Huỳnh Văn Hiền (2015), diện tích ao nuôi có ảnh hưởng đến năng suất tôm và tỉ suất lợi nhuận. Diện tích ao nuôi càng lớn thì năng suất và tỉ suất lợi nhuận lại có xu hướng càng giảm, và ở diện tích $2.000 \mathrm{~m}^{2} / \mathrm{ao}$ sẽ cho năng suất cao nhất. Theo Trần Ngọc Hải và ctv. (2017), độ sâu ao là yếu tố quan trọng trong nuôi tôm, ao quá sâu thường xảy ra tình trạng phân tầng nhiệt độ hay oxy trong ao, khó khăn gây màu nước, ao quá cạn thì các yếu tố môi trường dễ bị biến động theo ngày đêm, mực nước trong ao nên duy trì ở mức $1,3-1,6 \mathrm{~m}$.

\section{Bảng 2. Thông tin kỹ thuật của mô hình nuôi thâm canh tôm thẻ chân trắng}

\begin{tabular}{lrrr}
\hline Nội dung & Nhỏ nhất & Lớn nhất & Trung bình \pm độ lệch chuẩn \\
\hline Tổng diện tích trang trại (ha) & 0,4 & 15 & $1,87 \pm 2,70$ \\
Tồng diện tích ao nuôi (ha) & 0,1 & 1 & $0,21 \pm 0,21$ \\
Diện tích trung bình ao nuôi (ha) & 0,05 & 0,25 & $0,11 \pm 0,04$ \\
Độ sâu mực nước ao nuôi (m) & 0,8 & 1,2 & $1,5 \pm 0,1$ \\
Diện tích ao lắng (ha) & 0,05 & 1,2 & $0,27 \pm 0,22$ \\
Diện tích xử lý chất thải (ha) & 0,03 & 0,5 & $0,3 \pm 0,2$ \\
Diện tích ao xứ lý chất thải (ha/hộ) & 0,03 & 0,5 & $0,13 \pm 0,11$ \\
Ương giống (\%) & & & 80 \\
Mật độ thả nuôi thịt (con/m²) & 85 & 550 & $253 \pm 109$ \\
Thời gian nuôi (ngày) & 40 & 95 & $82,7 \pm 13,6$ \\
Kích cỡ thu hoạch (g/con) & 2,5 & 40 & $14,8 \pm 14,1$ \\
Tỷ lệ sống & 11,1 & 90,0 & $57,0 \pm 22,4$ \\
Năng suất (tấn/1.000 m²/vụ) & 0,4 & 8 & $3,97 \pm 1,92$ \\
FCR & 1,04 & 2 & $1,3 \pm 0,2$ \\
Kiểm tra môi trường (ngày/lần) & 1 & 7 & $2,1 \pm 1,9$ \\
Tần suất thay nước (ngày/lần) & 1 & 15 & $2,6 \pm 3,0$ \\
\hline
\end{tabular}

(Nguồn: Kết quả khảo sát năm 2019, $n=30$ ) 
Diện tích ao lắng và ao xử lý chất thải chiếm tỷ lệ khá lớn (124,9\% và 58,6\%) so với tổng diện tích ao nuôi hiện có nhưng chỉ chiếm $14,3 \%$ và $6,71 \%$ so với tổng diện tích trang trại. Có sự khác nhau này là do một số thành viên có tổng diện tích trang trại lớn, với nhiều ao nuôi nhưng tại thời điểm nghiên cứu chỉ có một số ao được thả nuôi và sử dụng ao lắng và ao xử lý nước thải cho cả trang trại. Các hộ nuôi trong mô hình đã nhận thức được tầm quan trọng của việc quản lý chất lượng nước với hiệu quả của quá trình nuôi, không có hộ nào cấp nước trực tiếp từ sông, kênh cho ao nuôi mà nước cấp đều phải qua hệ thống ao lắng, nước đã được xử lý trước khi cấp vào ao nuôi. Ao lắng giúp cải thiện chất lượng nước, hạn chế dịch bệnh trước khi cho vào ao nuôi, thường chiếm từ $20-25 \%$ tổng diện tích và ao xử lý chất thải giúp xử lý, lắng lọc chất thải trước khi đưa ra ngoài nhằm làm giảm ô nhiễm môi trường, thường chiếm từ $10-15 \%$ tổng diện tích ao nuôi (Trần Ngọc Hải và ctv., 2017).

Theo Hoàng Tùng và ctv. (2016), chất lượng con giống quyết định đến $60 \%$ mức độ thành công của vụ nuôi mặc dù chi phí mua con giống chỉ chiếm 6$8 \%$. Kết quả khảo sát có $100 \%$ hộ trả lời con giống trước khi thả nuôi đều được kiểm dịch các loại bệnh, trong đó có $63,3 \%$ tôm giống được kiểm tra bởi doanh nghiệp bán tôm, 30\% được kiểm kiểm tra qua HTX và $6,7 \%$ qua người quen. Do không trực tiếp kiểm tra dịch bệnh trên con giống nên chất lượng con giống còn tùy thuộc nhiều vào uy tín của doanh nghiệp bán tôm. Vì vậy người nuôi cần mua giống của những doanh nghiệp hay trại sản xuất có uy tín. Trước khi mua cần tìm hiểu nguồn góc của bể giống, đánh giá chất lượng giống bằng cảm quan và gửi mẫu xét nghiệm để đảm bảo tôm sạch bệnh. Ương giống là khâu quan trọng và phổ biến trong qui trình nuôi tôm 2 giai đoạn, được nhiều hộ nuôi thực hiện với $80 \%$ số hộ có ương giống với thời gian từ $15-$ 40 ngày và $20 \%$ thả nuôi trực tiếp do không có ao ương. Tôm sau quá trình ương có kích cỡ lớn, khỏe để thả nuôi và đảm bảo tỷ lệ sống, quản lý, cho ăn và chăm sóc thuận lợi giúp giảm giá thành sản xuất và giảm rủi ro ở những tháng đầu của chu kỳ nuôi (Châu Tài Tảo và ctv., 2015; Trần Ngọc Hải và ctv., 2017).

Mật độ thả nuôi trung bình của các thành viên HTX là $253 \mathrm{con} / \mathrm{m}^{2}$ là cao so với $75 \mathrm{con} / \mathrm{m}^{2}$ (Nguyễn Thanh Long \& Huỳnh Văn Hiền, 2015); 90 con $/ \mathrm{m}^{2}$ (Võ Nam Sơn và ctv., 2014) và $152 \mathrm{con} / \mathrm{m}^{2}$ (Phùng Thị Hồng Gấm và ctv., 2014). Mật độ tôm thả nuôi phụ thuộc vào trình độ kỹ thuật của người nuôi về chăm sóc và quản lý sức khỏe tôm, khả năng đầu tư trang thiết bị, thức ăn, hóa chất, mức độ hoàn chỉnh của hệ thống ao nuôi, mùa vụ thả nuôi và kích cỡ tôm nuôi (Trần Ngọc Hải và ctv., 2017). Ngoài ra, mật độ thả nuôi còn có liên quan đến kích cỡ thu hoạch và giá bán. Theo khuyến cáo của Sở Nông nghiệp và Phát triển Nông thôn tỉnh Cà Mau (2018), thì mật độ thả nuôi của tôm thẻ chân trắng siêu thâm canh nên giới hạn từ $150-250 \mathrm{con} / \mathrm{m}^{2}, 200-500$ $\mathrm{con} / \mathrm{m}^{2}$ (Hoàng Tùng và ctv., 2016) hay 300 - 600 $\mathrm{con} / \mathrm{m}^{2}$ (Trần Ngọc Hải và ctv., 2017) nếu ao nuôi được đầu tư trang thiết bị hiện đại, có ứng dụng công nghệ vào mô hình, trình độ kỹ thuật của người nuôi cao, khả năng quản lý ao tốt, các yếu tố môi trường được kiểm soát chặt chẽ. Lưu Hoàng Ly (2003), Nguyễn Thanh Phương và ctv. (2008) và Lâm Thị Ngọc Trân (2008) cho rằng khi mật độ thả càng cao thì khả năng rủi ro cao, đầu tư cao và hiệu suất đồng vốn thấp (trích bởi Trần Ngọc Hải và ctv 2017).

Thời gian nuôi phụ thuộc vào giá bán tôm, kỹ thuật nuôi và nhu cầu tôm trên thị trường. Thời gian nuôi tôm trung bình của các thành viên là khoảng 82,7 ngày với hệ số chuyển hóa thức ăn (FCR) trung bình 1,3 và tỷ lệ sống trung bình $57 \%$. Trong nghiên cứu của Nguyễn Thanh Long và Huỳnh Văn Hiền (2015) khảo sát trên các hộ nuôi tôm thẻ chân trắng nuôi ở Cà Mau cho thấy có $\mathrm{FCR}$ là 1,07 và tỷ lệ sống là $71 \%$. Một số thành viên nuôi tôm có thời gian nuôi ngắn (40 ngày) và tỷ lệ sống thấp do dịch bệnh trong quá trình nuôi nên phải thu hoạch sớm.

Theo Hoàng Tùng và ctv. (2016), năng suất tôm thẻ biến động lớn giữa các vùng nuôi, trang trại nuôi và phụ thuộc vào mức độ đầu tư trang thiết bị phục vụ sản xuất, trình độ và khả năng quản lý của người nuôi, điều kiện tự nhiên và dịch bệnh. Năng suất tôm nuôi và kích cở tôm thu hoạch có sự dao động lớn giữa các thành viên khảo sát, thấp nhất 0,4 tấn/1.000 $\mathrm{m}^{2} / \mathrm{vụ}(2,5 \mathrm{~g} / \mathrm{con})$ và cao nhất là 8 tấn $/ 1.000 \mathrm{~m}^{2} / \mathrm{vụ}$ (40 g/con) (Bảng 2). Một số thành viên thu hoạch tôm có kích cỡ nhỏ $(400 \mathrm{con} / \mathrm{kg})$ do dịch bệnh nên phải thu hoạch sớm trong quá trình nuôi. Trần Ngọc Hải và ctv. (2017) cho rằng tôm thẻ chân trắng nuôi ở mật độ $300-600 \mathrm{con} / \mathrm{m}^{2}$ có thể đạt năng suất từ 2 - 10 tấn $/ 1.000 \mathrm{~m}^{2} / \mathrm{vụ}$. Theo Nguyễn Thanh Long và Huỳnh Văn Hiền (2015), ở mật độ nuôi khoảng 75 $\mathrm{con} / \mathrm{m}^{2}$ sau 3 tháng nuôi năng suất tôm thẻ đạt trung bình 6,3 tấn/ha/vụ và năng suất sẽ giảm khi mật độ vượt $100 \mathrm{con} / \mathrm{m}^{2}$.

Giá bán phụ thuộc vào kích cỡ thu hoạch, màu sắc tôm, mùa vụ và thương lái. Giá tôm càng cao khi kích cỡ tôm càng lớn. Giá tôm có sự biến động lớn theo kích cỡ thu hoạch. Do sự biến động lớn của năng suất và giá bán nên tổng thu nhập của mô hình 
dao động từ 12 triệu đồng/1.000 m²/vụ đến 960 triệu đồng/1.000 m²/vụ (Bảng 2).

Kết quả khảo sát còn cho thấy các hộ nuôi tôm rất chú trọng đến quản lý chất lượng nước ao nuôi, điều này thể hiện ở tần suất thay nước và theo dõi sự biến động các yếu tố môi trường nước trong quá trình nuôi. Chu kỳ thay nước trung bình là 2,6 ngày/lần, và đo các yếu tố môi trường là 2,1 ngày/lần. Các yếu tố môi trường được kiểm tra thường xuyên trong quá trình nuôi là $\mathrm{pH}$, kiềm và khí độc vì đây là những yếu tố quan trọng ảnh hưởng đến sức khỏe tôm nuôi nên cần được theo dõi thường xuyên nhằm phát hiện những thay đổi và có giải pháp xử lý kịp thời.

\subsection{Chỉ tiêu tài chính của mô hình nuôi thâm canh tôm thẻ chân trắng tại HTX Tân Hurng}

Với tổng chi phí đầu tư trung bình vào mô hình nuôi của thành viên là $329 \pm 131$ triệu đồng/1.000 $\mathrm{m}^{2}$ thì chi phí thức ăn chiếm tỷ lệ cao nhất $(48,2 \%)$, chi chi phí thuốc, hóa chất chiếm $21,1 \%$ và con giống chiếm 8,3\% (Bảng 3, Hình 1). Nguyễn Thanh Long và Huỳnh Văn Hiền (2015) cũng nhận định chi phí thức ăn, con giống và thuốc hóa chất là 3 chi phí chiếm tỷ lệ cao nhất rong mô hình nuôi tôm thẻ chân trắng ở Cà Mau. Theo Đỗ Minh Vạnh và ctv. (2016), chi phí thức ăn trong mô hình nuôi tôm thẻ chân trắng thâm canh ở các hình thức tổ chức sản xuất nông hộ, tổ hợp tác, trang trại và doanh nghiệp dao động từ $45,9-58,5 \%$, chi phí con giống chiếm từ $10,3-14,6 \%$ và chi phí thuốc hóa chất chiếm từ 7,44 - 12,6\%. Bên canh đó, chi phí nhiên liệu (điện) sử dụng trong quá trình nuôi của hộ là khá cao chiếm $6,4 \%$ tổng chi phí vì vùng nuôi của HTX hiện tại chỉ có lưới điện 1 pha nên điện rất yếu, không đảm bảo vận hành tốt hệ thống sục khí và quạt nước của mô hình nuôi tôm trên bể lót bạt, trong khi đó giá điện lại rất cao do nông hộ sử dụng vược định mức cho hộ gia đình theo qui định. Theo Võ Nam Sơn và ctv. (2018), mô hình nuôi tôm thẻ trong ao lót bạt có chỉ số tiêu hao điện là $3.253 \mathrm{~kW}$.h/tấn tôm hay chi phí điện để sản xuất $1 \mathrm{~kg}$ tôm là 5.085 đồng

\section{Bảng 3. Thông tin tài chính của mô hình nuôi thâm canh tôm thẻ chân trắng}

(ĐVT: triệu đồng)

\begin{tabular}{|c|c|c|c|}
\hline Nội dung & Thấp nhất & Cao nhất & Trung bình \pm độ lệch chuẩn \\
\hline Giá bán $(1.000$ d/kg) & 30 & 158 & $111 \pm 26$ \\
\hline Chi phí cố định (trđ/1000m²/vụ) & 67 & 500 & $217,4 \pm 106,8$ \\
\hline Chi phí khấu hao (trđ/1000m²/vụ) & 3,33 & 26,7 & $10,6 \pm 5,4$ \\
\hline Tổng chi biến đổi ( $\left.\operatorname{trd} / 1000 \mathrm{~m}^{2} / \mathrm{vụ}\right)$ & 75,8 & 581,5 & $318,1 \pm 129,9$ \\
\hline Tổng chi (trđ/1000m²/vụ) & 85,8 & 594,9 & $328,7 \pm 131$ \\
\hline Tổng thu (trđ/ $\left.1000 \mathrm{~m}^{2} / \mathrm{vụ}\right)$ & 12 & 960 & $466 \pm 260,5$ \\
\hline Lợi nhuận (trd/1000m²/vụ) & $-164,7$ & 418,4 & $137,3 \pm 160,7$ \\
\hline Lợi nhuận/Chi phí (lần) & $-1,92$ & 0,7 & $0,42 \pm 1,23$ \\
\hline
\end{tabular}

(Nguồn: Kết quả khảo sát năm 2019, n= 30)

" Khấu hao

" Nhân công

" Nhiên liệu

" Thức ăn

- Con giống

" Thuốc hóa chất

- Cài tạo

- Khác

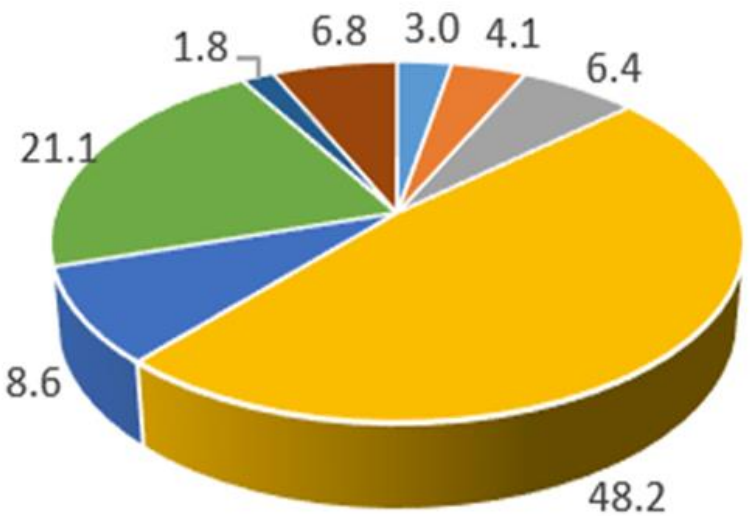

Hình 1. Cơ cấu chi phí của mô hình nuôi tôm thẻ chân trắng 
Với tổng chi phí và tổng thu nhập có sự chênh lệch lớn giữa các thành viên nên lợi nhuận cũng có sự thay đổi lớn từ lỗ 165 triệu đồng/1.000 m²/vụ đến lãi 418 triệu đồng/1.000 m²/vụ (Bảng 3). Tỷ suất lợi nhuận trong nghiên cứu này thấp hơn so với kết quả các nghiên cứu trước đây. Trong nghiên cứu của Nguyễn Thanh Long và Huỳnh Văn Hiền (2015), các mô hình nuôi tôm thẻ chân trắng ở Cà Mau có tỷ suất lợi nhuận là 1,66. Đỗ Minh Vạnh và ctv. (2016) khảo sát về hiệu quả nuôi tôm thẻ chân trắng thâm canh theo các hình thức tổ chức ở ĐBSCL có tỷ suất lợi nhuận dao động từ 0,85-1.04. Tỷ lệ hộ nuôi có lãi là $23 / 30$ hộ $(76,7 \%)$ và $7 / 30$ hộ nuôi bị lỗ $(23,3 \%)$ tập trung chủ yếu ở các thành viên bị rủi ro dịch bệnh trong quá trình nuôi, tôm buộc phải thu hoạch sớm khi kích cỡ nhỏ và giá bán thấp. Do vậy, để tăng lợi nhuận của mô hình nuôi, hạn chế dịch bệnh các thành viên cần phải tuân thủ qui trình kỹ thuật nuôi từ khâu chuẩn bị hệ thống ao nuôi, chọn giống, mật độ thả, cho ăn và quản lý thức ăn phù hợp, sử dụng thuốc hóa chất một cách khoa học, quản lý môi trường có ứng dụng công nghệ sinh học cũng cần được áp dụng.

\subsection{Hiện trạng hoạt động và những lợi ích khi tham gia HTX của thành viên}

3.4.1. Hiện trạng hoạt động của HTX Nuôi tôm Năng suất cao Tân Hưng

HTX Nuôi tôm Năng suất cao Tân Hưng được thành lập ngày 01/6/2016 ha tại ấp Bào Vũng, xã Tân Hưng, huyện Cái Nước, tỉnh Cà Mau với số thành viên ban đầu là 19 và tổng diện tích nuôi tôm là 21 ha. HTX hoạt động dưới dạng liên kết theo chuỗi sản xuất và dịch vụ đầu vào gắn tiêu thụ sản phẩm. Với tổng số vốn điều lệ là 1,20 tỷ đồng. Cuối năm 2016, số thành viên hợp tác xã tăng lên đạt 31 thành viên, trong đó số cán bộ quản lý HTX là 10 người có trình độ đại học và sau đại học gồm Hội đồng quản trị (có 4 thành viên), 1 giám đốc, 2 thành viên Ban kiểm soát, 1 kế toán viên và 2 kỹ thuật viên. Tổng diện tích nuôi tôm của HTX là 35 ha. Sau 3 năm thành lập, năm 2019 số thành viên HTX tăng lên 45 thành viên và diện tích nuôi tôm khoảng 100 ha.

Kết quả sản xuất kinh doanh của HTX năm 2016 đạt 1,55 tỷ đồng doanh thu với lợi nhuận khoảng 348 triệu đồng. Thu nhập bình quân của thành viên là 50 triệu đồng/năm và thu nhập bình quân người lao động là 45 triệu đồng/năm. Sản lượng tôm của thành viên cao nhất và thấp nhất lần lượt là 15 tấn/ha/năm và 8 tấn/ha/năm. Sau 3 năm hoạt động, năm 2019 HTX đạt 12,99 tỷ đồng doanh thu với lợi nhuận trước thuế là 1,85 tỷ, trong đó phân chia lợi nhuận cho các thành viên là 1,3 tỷ theo tỷ lệ góp vốn đầu tư và sử dụng dịch vụ của HTX. Thu nhập bình quân của thành viên là 68 triệu đồng/năm và thu nhập bình quân của người lao động là 60 triệu đồng/năm. Sản lượng tôm của thành viên HTX cao nhất là 80 tấn/ha/năm và thấp nhất là 30 tấn/ha/năm.

\subsubsection{Lơi ich khi tham gia HTX của thành viên}

Trong Bản tuyên ngôn về các đặc trưng của HTX, Liên Minh HTX Quốc tế định nghĩa "HTX là một hiệp hội (association) tự chủ do các cá nhân tự nguyện liên kết với nhau nhằm thỏa mãn nhu cầu và nguyện vọng chung về kinh tế, xã hội và văn hóa thông qua việc hình thành doanh nghiệp (enterprise) do tập thể thành viên đồng sở hữu và quản lý dân chủ.” (Tổ chức Lao động Quốc tế, 2011). Kết quả khảo sát tại HTX Tân Hưng cho thấy bên cạnh lợi ích kinh tế thì lợi ích mang lại từ khía cạnh hiệp hội khi trở thành thành viên của HTX cũng là lý do thu hút người dân trở thành thành viên HTX (Bảng 4).

Những lợi ích về kinh tế được thể hiện rõ nét qua đánh giá của thành viên khi tham gia HTX. Doanh thu và lợi nhuận của hộ nuôi tôm tăng lên được đánh giá bởi 93,3\% thành viên. Sự gia tăng lợi nhuận có sự đóng góp của nhiều yếu tố như giảm chi phí sản xuất, tăng sản lượng và chất lượng tôm. Với việc tiếp cận các hỗ trợ từ dịch vụ của HTX, thành viền tiết kiệm được $10,1 \%$ chi phí sản xuất so với trước khi tham gia vào HTX. Có đến $80,0 \%$ thành viên cho rằng sản lượng tôm của họ tăng lên so với trước. Ở tiêu chí giá bán tôm, có $33,3 \%$ thành viên tin rằng việc tham gia HTX góp phần làm giá bán ổn định hơn trước.

Về khía cạnh hiệp hội, kết quả khảo sát cho thấy $100 \%$ thành viên được doanh nghiệp cung ứng vật tư đầu vào với giá và dịch vụ ưu đãi so với khách hàng bên ngoài HTX. Chẳng hạn như thức ăn giá mua tiền mặt thấp hơn $6.000 \mathrm{~d} / \mathrm{kg}$, trả sau thấp hơn 1.000 đ $/ \mathrm{kg}$; thuốc và hóa chất mua tiền mặt thấp hơn $20 \%$, mua trả sau thấp hơn $10-15 \%$ tùy mặt hàng. Đối với con giống, tuy không được giảm giá nhưng để đảm bảo chất lượng con giống bên cung ứng sẽ đền bù $100 \%$ chi phí con giống nếu có sự cố trong tháng đầu tiên với điều kiện chất lượng môi trường nước vẫn đảm bảo. Các vật tư đầu vào sẽ được cung cấp trực tiếp đến các thành viên khi nhận được yêu cầu như tổ chức giao thuốc và thức ăn đến tận nhà thành viên khi nhận được đơn hàng để đảm bảo chất lượng và kiểm tra, giám sát tình hình nuôi và bảo quản thuốc, thức ăn đạt hiệu quả cao nhất. Từ đó cho thấy thời gian qua HTX đã ký kết hợp đồng liên kết với các doanh nghiệp cung ứng vật tư đầu vào như thức ăn, thuốc hóa chất, con giống nhằm tạo điều 
kiện cho các xã viên mua vật tư đầu vào trực tiếp từ doanh nghiệp với giá rẽ hơn so với các cửa hàng. Bên cạnh đó, do các thành viên HTX tập hợp mua chung (cung ứng tập trung) nên giá thấp hơn so với từng hộ mua nhỏ lẻ. Dịch vụ giao hàng được thuận lợi và chất lượng được đảm bảo. Ngoài ra các doanh nghiệp cung cấp vật tư đầu vào thường kèm theo các dịch vụ hỗ trợ, tư vấn kỹ thuật cho các thành viên HTX trong quá trình nuôi. Nông hộ khi trở thành thành viên HTX nhận được nhiều hỗ trợ về kỹ thuật áp dụng vào sản xuất. Kết quả khảo sát có đến $93,3 \%$ thành viên được tiếp cận dịch vụ hỗ trợ kỹ thuật từ các kỹ thuật viên của HTX. Các doanh nghiệp cung ứng đầu vào luôn hỗ trợ về kỹ thuật nuôi, các dịch vụ cho thành viên HTX khi có yêu cầu như kiểm tra mẫu nước, xét nghiệm một số bệnh trên tôm, tư vấn cách phòng, trị bệnh cũng như cách sử dụng thuốc, hóa chất. Thật vậy, trong thời gian qua HTX đã sử dụng các nguồn hỗ trợ để xoay vòng giúp các thành viên cải thiện tình trạng ao nuôi, đồng thời tạo được sự đoàn kết, thống nhất, năng động giữa các thành viên của HTX trong việc tổ chức sản xuất kinh doanh. Ngoài ra, HTX luôn học hỏi và chủ động tiếp cận tiến bộ khoa học kỹ thuật, ứng dụng công nghệ mới vào sản xuất, đầu tư trang thiết bị máy móc để giảm sức lao động, với $100 \%$ thành viên nuôi tôm có sử dụng bể lót bạt, hệ thống cho tôm ăn tự động và ứng dụng công nghệ biofloc trong giai đoạn đầu của quá trình nuôi. Ngoài ra HTX còn là đầu mối tiếp nhận những chương trình, dự án hỗ trợ phát triển thủy sản, chuyển giao khoa học kỹ thuật, công nghệ tiên tiến, mô hình nuôi tôm thâm canh, siêu thâm canh. Tổ chức các lớp tập huấn kỹ thuật cũng như tham quan các mô hình nuôi tôm hiệu quả cho các thành viên với $100 \%$ thành viên $\mathrm{HTX}$ tham gia từ $1-3$ lớp tập huấn về kỹ thuật nuôi tôm. Nhờ đó, thành viên được tiếp cận, ứng dụng khoa học, kỹ thuật canh tác mới giúp tăng năng suất, tăng chất lượng sản phẩm và tăng thu nhập

Bảng 4. Lợi ích khi tham gia HTX của thành viên

\begin{tabular}{lcc}
\hline Lợi ích khi tham gia & Tần số & Tỷ lệ (\%) \\
\hline Khía cạnh kinh tế & & \\
\hline Tăng doanh thu và lợi nhuận & 28 & 93,3 \\
Tăng sản lượng & 24 & 80,0 \\
Giá bán tôm ồn định & 10 & 33,3 \\
\hline Khía cạnh hiệp hội & 30 & 100 \\
\hline Được ưu đãi giá và dịch vụ khi mua vật tư đầu vào & 28 & 93,3 \\
Được hồ trợ về kỹ thuật & 23 & 76,7 \\
Chầt lượng đầu ra sản phẩm tốt hơn & 21 & 70,0 \\
Tạo liên kết và môi trường hợp tác & 16 & 53,3 \\
Được trao đổi và chia sẻ kinh nghiệm sản xuất & &
\end{tabular}

(Nguồn: Kết quả khảo sát năm 2019, $n=30$ )

Hiện trạng hoạt động của các HTX ở ĐBSCL tập trung chủ yếu ở dịch vụ đầu vào như cung cấp giống, vật tư, chuyển giao kỹ thuật nhưng hạn chế trong các hoạt động chế biến, tiêu thụ sản phẩm (Mai Văn Nam, 2005). Đỗ Minh Vạnh và ctv. (2016) cũng ghi nhận rằng với hình thức sản xuất là tổ hợp tác thì tôm được bán chủ yếu thông qua thương lái (100\%), trong khí đó ở hình thức sản xuất công ty thì $100 \%$ bán cho doanh nghiệp thu mua, hình thức nông hộ và trang trại bán cho cả thương lái và doanh nghiệp thu mua. Do vậy, tìm đầu ra ổn định cho sản phẩm là một trong những kỳ vọng quan trọng của thành viên khi tham gia HTX. Sự ổn định giá bán có sự đóng góp của yếu tố chất lượng tôm bán ra như màu sắc của tôm, kết quả kiểm tra kháng sinh, ngoại hình không thương tích, kích cỡ để thương lái định giá mua. Kết quả khảo sát cho thấy có đến $76,7 \%$ thành viên cho rằng chất lượng tôm bán ra cao hơn từ khi họ trở thành thành viên HTX. Tuy chưa tạo được liên kết tiêu thụ đầu ra trực tiếp với các doanh nghiệp chế biến tôm xuất khẩu nhưng HTX đã tổ chức bán trực tiếp cho các thương lái và đại lý thu mua tôm với giá cả thường cao hơn giá thị trường và phương thức thanh toán rõ ràng, nhanh chóng. Hiện tại HTX đã ký kết bản ghi nhớ với Doanh nghiệp cổ phần Camimex trong việc tiêu thụ sản phẩm của các thành viên HTX. Các điều kiện hợp đồng với Doanh nghiệp cổ phần Camimex về thu mua như chất lượng tôm, kích cỡ, điều kiện bảo quản và vận chuyển tôm nguyên liệu được HTX phổ biến đến tất cả các thành viên và yêu cầu các thành viên nghiêm túc thực hiện trong quá trình sản xuất, đặc biệt nghiêm cấm việc sử dụng thuốc kháng sinh, hóa chất cấm. Các thành viên tham gia HTX trong thời gian qua đã thực hiện tốt những khuyến cáo từ HTX trong quá trình sản xuất. Thật vậy, mặc dù tôm của thành viên HTX chính thức chưa đạt bất kỳ tiêu chuẩn nào như VietGAP hay ASC nhưng thời gian qua HTX luôn 
định hướng và đề nghị thành viên sản xuất theo hướng tôm sạch và an toàn, hạn chế tối đa việc sử dụng các loại hóa chất và kháng sinh. Điều này thể hiện ở nhận định của các thành viên về chất lượng tôm bán ra cao hơn $(76,7 \%)$ và giá bán ổn định hơn $(33,3 \%)$. Ngoài ra, HTX và các thành viên cũng đã được hỗ trợ, tư vấn cụ thể hóa các yêu cầu của doanh nghiệp chế biến thủy hải sản xuất khẩu cho các thành viên HTX thực hành theo như nguồn nguyên liệu cung cấp cho doanh nghiệp được nuôi trong nguồn nước không có dư lượng thuốc trừ sâu, không dùng thức ăn và thuốc chữa bệnh có thành phần cấm, các kháng sinh khác nếu có sử dụng thì sau ít nhất 1 tháng mới được thu hoạch tôm, tôm nguyên liệu phải đảm bảo tươi, không bị dập nát, không có mùi lạ, không có tạp chất lạ (Agar), không sử dụng các chất sulfit trong bảo quản, nơi thu mua phải được vệ sinh và dễ khử trùng và có vòi nước sạch rửa nguyên liệu trước khi bảo quản, đá cây để muối ướp phải được mua từ nơi sản xuất đá sạch, các dụng cụ bảo quản phải là dụng cụ cách nhiệt tốt, dễ vệ sinh, dễ khử trùng, đảm bảo duy trì nhiệt độ nguyên liệu đạt yêu cầu trong suốt quá trình bảo quản và vận chuyển,...

Kết quả khảo sát cũng cho thấy có $70,0 \%$ thành viên $\mathrm{HTX}$ cho rằng họ tham gia vào $\mathrm{HTX}$ vì sự liên kết sẽ tạo nên sức mạnh, tạo môi trường hợp tác cùng nhau phát triển và giúp thành viên, giúp HTX có tiếng nói hơn trong việc trao đổi với các bên liên quan trong chuỗi giá trị ngành hàng tôm. Ngoài ra, tham gia HTX sẽ tạo môi trường thúc đẩy việc chia sẻ, hô̂ trợ trao đổi kinh nghiệm trong sản xuất và cuộc sống, giúp các thành viên HTX phát triển tốt hơn là ý kiến của $53,3 \%$ thành viên.

Từ những lợi ích mang lại khi tham gia HTX cho thấy khi tham gia vào HTX thành viên có nhiều lợi ích về kinh tế và khía cạnh hiệp hội. Một nghiên cứu khác của Trần Quốc Nhân và ctv. (2012) cũng chỉ ra rằng hộ tham gia HTX có nhiều lợi ích hơn so với hộ không tham gia như tỷ lệ thành viên HTX tham gia các khóa tập huấn chiếm $92,3 \%$ so với các hộ không tham gia HTX là $54,3 \%$; có $61,5 \%$ thành viên tham gia HTX được tham quan học hỏi từ các mô hình sản xuất so với $11,4 \%$ không tham gia HTX, $38,5 \%$ thành viên tham gia HTX được tiếp cận và mua vật tư đầu vào trực tiếp từ công ty với giá rẽ hơn so với $11,4 \%$ không tham gia HTX, trong vấn đề tiêu thụ sản phầm thì có $97,1 \%$ hộ không tham gia HTX bán sản phầm trực tiếp cho thương lái không qua hợp đồng trong khi đó chỉ có 61,5\% thành viên HTX bán qua hình thức này.
Bên cạnh những lợi ích HTX mang lại cho các thành viên, HTX còn gặp một số hạn chế trong quá trình hoạt động, đặc biệt tiếp cận tín dụng là một trong những khó khăn nhất của HTX nông nghiệp. Theo Mai Văn Nam (2005), vốn là một trong những yếu tố quan trọng trong việc thành lập và hoạt động của $\mathrm{HTX}$, chính những hộ thiếu vốn cho nên khi vào HTX phần vốn góp cũng rất ít. Mặc dù có nhiều chính sách hỗ trợ tiếp cận vốn vay cho HTX nhưng thực tế số lượng và tỷ lệ các HTX tiếp cận được các chính sách rất thấp. Trong 12 nhóm chính sách hỗ trợ được thống kê hàng năm, cao nhất mới có khoảng gần 3\%, thấp nhất có nhóm chỉ đạt $0,13 \%$ số HTX nông nghiệp tiếp cận được chính sách. Những nhóm chính sách quan trọng để hỗ trợ các HTX thực hiện tốt vai trò của HTX trong việc giúp nông dân liên kết gắn sản xuất với tiêu thụ nông sản, an toàn và có giá trị cao như các chính sách tiếp cận tín dụng, hỗ trợ phát triển kết cấu hạ tầng, hỗ trợ khoa học công nghệ, sơ chế và chế biến sản phẩm hay tiếp thị sản phẩm,... đều đạt tỷ lệ rất thấp (Bộ Nông nghiệp và Phát triển Nông thôn, 2016). Tìm đầu ra cho sản phẩm cũng là một trong những khó khăn của HTX. Tuy đã ký kết bản ghi nhớ với doanh nghiệp chế biến thủy hải sản xuất khẩu Camimex nhưng HTX cần được hỗ trợ, tư vấn theo dõi thường xuyên nhằm đảm bảo các thành viên thực hành tốt các tiêu chuẩn yêu cầu đặt ra từ phía doanh nghiệp chế biến. Ngoài ra, năng lực điều hành của lãnh đạo HTX chưa thật sự năng động, bài bản trong công tác tiếp cận thị trường, đã tham gia nhiều lớp tập huấn về HTX nhưng chưa ứng dụng và chia sẻ thông tin lại nhiều cho thành viên do bận rộn với công tác quản lý, các nội dung tập huấn thường thuần lý thuyết trong thời gian ngắn nên người tham dự tập huấn chưa đủ năng lực áp dụng. Thành viên HTX chưa tích cực thể hiện nhiệm vụ, còn trông chờ nhiều vào sự hỗ trợ của nhà nước. Số lượng thành viên tuy là đông nhưng xét về quy mô sản xuất thì còn nhỏ lẻ, chưa theo qui trình cụ thể nên sản phẩm chưa đạt được chứng nhận tiêu chuẩn nào. Chưa xây dựng được niềm tin giữa các bên liên kết, đặc biệt là tiêu thụ sản phẩm. Tỷ lệ thành viên hạn chế về đọc viết còn cao, địa bàn các thành viên cư trú rải rác nên khó tổ chức thành khu vực cho công tác tổ chức, quản lý sản xuất.

Nhìn chung, với tuổi đời còn non trẻ nhưng HTX Nuôi tôm Năng suất cao Tân Hưng đáp ứng tốt kỳ vọng của thành viên. HTX đã đảm bảo lợi ích nhiều nhất cho các thành viên với kết khảo sát có đến $93,3 \%$ thành viên đánh giá HTX đã làm tốt vai trò của mình trong đáp ứng nhu cầu khi tham gia. 


\section{KẾT LUẬN VÀ ĐỀ XUẤT}

\subsection{Kết luận}

Tham gia vào các hoạt động sản xuất tại nông hộ chủ yếu là nam giới trong độ tuổi lao động nhưng trình độ học vấn của nông hộ còn thấp. Tỷ suất lợi nhuận của mô hình chưa cao so với chi phí đầu tư. Số thành viên, diện tích sản xuất, doanh thu và thu nhập bình quân của thành viên tại HTX gia tăng sau 3 năm thành lập HTX. Những lợi ích khi tham gia vào $\mathrm{HTX}$ được thành viên đánh giá qua lợi ích kinh tế và khía cạnh hiệp hội. Về lợi ích kinh tế như tăng doanh thu và lợi nhuận, tăng sản lượng tôm và giá bán ổn định; Khía cạnh hiệp hội là được ưu đãi giá và dịch vụ khi mua vật tư đầu vào, được hỗ trợ về kỹ thuật, chất lượng đầu ra sản phẩm tốt hơn, tạo liên kết và môi trường hợp tác, được trao đổi và chia sẽ kinh nghiệm trong sản xuất. Các khó khăn của HTX là thiếu vốn, tìm đầu ra cho sản phẩm, năng lực điều hành của lãnh đạo HTX còn hạn chế, thành viên HTX chưa tích cực và còn trông chờ nhiều vào sự hỗ trợ, qui mô sản xuất còn nhỏ lẻ, chưa xây dựng được niềm tin giữa các bên liên kêt và tỷ lệ thành viên hạn chế về đọc viết còn cao.

\section{2. Đề $x u a ̂ ́ t$}

- Với hoạt động liên kết tổ chức sản xuất cần tiếp tục duy trì và củng cố liên kết với các doanh nghiệp cung ứng vật tư đầu vào trong việc ký kết hợp đồng cung ứng tập trung nhằm giảm chi phí cũng như tân dụng sự hỗ trợ từ các doanh nghiệp. Phát huy liên kết với doanh nghiệp chế biến thủy hải sản, đồng thời HTX phải thực hành tốt những tiêu chuẩn yêu cầu đặt ra từ phía doanh nghiệp chế biến thủy hải sản để nâng cao giá trị sản phẩm

- Cần xem xét lại các qui định, tiêu chí nhằm tạo điều kiện cho HTX tiếp cận với các chính sách hỗ trợ về vốn, ứng dụng kỹ thuật, xây dựng cơ sở hạ tầng (điện), chính sách về liên kết trong cung ứng đầuv vào và tiêu thụ sản phẩm,...

- Ban quản lý HTX cần tổ chức và giám sát tốt việc tuân thủ quy trình, kỹ thuật nuôi được khuyến cáo như mật độ thả nuôi, lịch thời vụ, chăm sóc, quản lý,,...

- Huấn luyện nâng cao năng lực về cách thức tổ chức, quản lý HTX khi thực hiện mô hình liên kết sản xuất, huấn luyện nâng cao trình độ kỹ thuật cho người nuôi tôm để sản xuất theo tiêu chuẩn nhằm nâng cao chất lượng và giá bán, đáp ứng yêu cầu của doanh nghiệp chế biến thủy hải sản

\section{TÀI LIỆU THAM KHẢO}

Adref, F. (2011). Agricultural Cooperatives for Agricultural Development in Iran. Life Science Journal, 8 (1), 82-83.

Bộ Nông nghiệp và Phát triển Nông thôn. (2016). Báo cáo sơ kết 3 năm thực hiện luật hợp tác xã và nhiệm vụ, giải pháp phát triển kinh tế hợp tác năm 2016 trong lĩnh vực nông nghiệp. (Số 2992/BC-BNN-KTHT).

http://www.mpi.gov.vn/Pages/tinbai.aspx?idTin= 36671\&idcm $=406$

Chambo, S. (2009). Agricultural Cooperatives: Role in Food Security and Rural Development. Paper Presented to Expert Group Meeting on Cooperatives, New York (USA).

http://citeseerx.ist.psu.edu/viewdoc/download?do $\mathrm{i}=10.1 \cdot 1.516 .7976 \&$ rep=rep1\&type=pdf.

Châu Tài Tảo, Hồ Ngọc Ngà và Trần Ngọc Hải (2015). Ảnh hưởng của mật độ lên tăng trưởng và tỷ lệ sống của tôm thẻ chân trắng (Litopenaeus vannamei) ương giống theo công nghệ Bio-floc. Tạp chi Khoa học, Trương Đại hoc Cần Tho, 37(1), 65-71.

Đỗ Minh Vạnh, Trần Hoàng Tuân, Trần Ngọc Hải \& Trương Hoàng Minh. (2016). Đánh giá hiệu quả nuôi tôm thẻ chân trắng thâm canh theo các hình thức tổ chức ở đồng bằng sông Cửu Long. Tạp chi Khoa học, Truờng Đại học Cần Tho', 42(2016), 50-57.

Hoàng Tùng, Michael Leger, Trần Quang Đại, Trần Anh Hoàng Sử \& Nguyễn Thị Thùy Vân. (2016). Thực hành nuôi tôm thẻ chân trắng bền vũng. Nhà xuất bản Nông nghiệp.

Lê Xuân Sinh, Đỗ Minh Chung, Phan Thị Ngọc Khuyên \& Từ Thanh Truyền. (2006). Tác động về mặt xã hội của hoạt động nuôi trồng thủy sản mặn lợ, ven biển Đồng bằng sông Cửu Long. Tạp chi Khoa hoc, Truờng Đại học Cần Tho, số chuyên đề (2), 220-234.

Liên minh hợp tác xã Việt Nam. (2018). Báo cáo thường niên 2018.

http://vca.org.vn/upload/file/tv.-ban-tachtrang.pdf.

Mai Văn Nam. (2005). Kinh tế hợp tác và vai trò của kinh tế hợp tác và hợp tác xã đối với phát triển sản xuất nông nghiệp vùng đồng bằng sông Cửu Long. Tạp chi Khoa hoc, Trương Đại hoc Cần Tho, 3(2005), 128-137.

Nguyễn Thanh Long. (2016). Phân tích hiệu quả tài chính của mô hình nuôi tôm sú thâm canh ở tỉnh Cà Mau. Tạp chí Khoa học, Trưòng Đại học Cần Tho, 46(1), 87-94. 
Nguyễn Thanh Long \& Huỳnh Văn Hiền. (2015). Phân tích hiệu quả kỹ thuật và tài chính của mô hình nuôi tôm thẻ chân trắng ở tỉnh Cà Mau. Tạp chi Khoa hoc, Truò̀ng Đại hoc Cần Tho', 37 (1), 105-111.

Nguyễn Thanh Phương, Nguyễn Anh Tuấn, Trần Ngọc Hải, Võ Nam Sơn \& Dương Nhựt Long. (2014). Giáo trình Nuôi trồng Thủy sản. Nhà xuất bản Đại học Cần Thơ.

Phùng Thị Hồng Gấm. (2014). Phân tích hiệu quả các mô hình nuôi tôm thẻ chân trắng và tôm sú thâm canh ở tỉnh Ninh Thuận. Tạp chi Khoa học, Truòng Đại học Cần Tho, số chuyên đề Thủy sản, (2), 37-43.

Sở Nông nghiệp và Phát triển Nông thôn. (2018). Quy trình kỹ thuật nuôi tôm thẻ chân trắng siêu thâm canh. 32 trang.

Tổ chức Lao động Quốc tế (2011). Kiến thức cơ bản về Hợp tác xã Nông nghiệp.

ilo.org/wcmsp5/groups/public/---ed_emp/--emp_ent/---

coop/documents/instructionalmaterial/wcms_64 5059.pdf.

Tổng cục Thống kê. (2019). Số liệu thống kê. www.gso.gov.vn.
Trần Ngọc Hải, Châu Tài Tảo \& Nguyễn Thanh Phương. (2017). Giáo trình Kỹ thuật sản xuất giống và nuôi giáp xác. Nhà xuất bản Đại học Cần Thơ.

Trần Quốc Nhân, Lê Duy, Đỗ Văn Hoàng \& Nguyễn Duy Cần. (2012). Phân tích lợi ích do hợp tác xã nông nghiệp kiểu mới mang lại cho người dân: Trường hợp nghiên cứu hợp tác xã Long Tuyền, quận Bình Thủy, Thành phố Cần Thơ. Tạp chi Khoa họ, Trưòng Đại hoc Cần Tho, 22b, 283-293.

VASEP. (2019). Tổng quan ngành thủy sản Việt Nam. http://vasep.com.vn/1192/OneContent/tong-quannganh.html.

Võ Nam Sơn, Trương Tấn Nguyên \& Nguyễn Thanh Phương. (2014). So sánh đặc điểm kỹ thuật và chất lượng môi trường giữa ao nuôi tôm sú và tôm thẻ chân trắng thâm canh tại tỉnh Sóc Trăng. Tạp chi Khoa hoc, Truờng Đại hoc Cần Tho; số chuyên đề Thủy sản (2), 70-78.

Võ Nam Sơn, Đào Minh Hải, Nguyễn Thế Diễn, Vũ Văn Thùy, Đinh Xuân Lập, Nguyễn Đỗ Quỳnh \& Nguyễn Thanh Phương. (2018). Phân tích hiệu quả sản xuất và sử dụng năng lượng điện trong nuôi tôm sú và thẻ chân trắng thâm canh và quảng cảnh cải tiến ở đồng bằng sông Cửu Long. Tạp chi Khoa hoc, Truò̀ng Đại học Cần Tho, 55(1B), 66-79. 